\title{
60 years of scientific deep drilling in Colombia: the north Andean guide to the Quaternary
}

\author{
Henry Hooghiemstra ${ }^{1}$, Gustavo Sarmiento Pérez ${ }^{2, a}$, Vladimir Torres Torres ${ }^{1,3}$, Juan-Carlos Berrío ${ }^{1,4}$, \\ Lucas Lourens ${ }^{5}$, and Suzette G. A. Flantua ${ }^{1,6,7}$ \\ ${ }^{1}$ Institute for Biodiversity and Ecosystem Dynamics, Department of Ecosystem and Landscape Dynamics, \\ University of Amsterdam, Science Park 904, 1098 XH Amsterdam, the Netherlands \\ ${ }^{2}$ Servicio Geológico de Colombia (Ingeominas), Bogotá, Colombia \\ ${ }^{3}$ Exploration and New Ventures, ExxonMobil, 22777 Springwoods Village Parkway, \\ Spring, Texas 77389, USA \\ ${ }^{4}$ Department of Geography, University of Leicester, Leicester, UK \\ ${ }^{5}$ Department of Geosciences, Utrecht University, Utrecht, the Netherlands \\ ${ }^{6}$ Department of Biological Sciences, University of Bergen, 5020 Bergen, Norway \\ ${ }^{7}$ Bjerknes Centre for Climate Research, University of Bergen, 5020 Bergen, Norway \\ ${ }^{a}$ currently at: Departamento de Geociencias, Universidad Nacional de Colombia, Bogotá, Colombia \\ Correspondence: Henry Hooghiemstra (h.hooghiemstra@uva.nl) and Suzette G. A. Flantua \\ (s.g.a.flantua@gmail.com)
}

Received: 30 October 2021 - Revised: 17 January 2022 - Accepted: 23 January 2022 - Published: 25 February 2022

\begin{abstract}
We sketch the initial history of collecting deep cores in terrestrial and marine sedimentary basins and ice cores to study environmental and climate change. Subsequently, we focus on the development of long records from the Northern Andes. The $586 \mathrm{~m}$ long pollen record from ancient Lake Bogotá reflects the last $2.25 \times 10^{6}$ years with $\sim 1.2 \mathrm{kyr}$ resolution, whereas the sediment core reflects almost the complete Quaternary. The $58 \mathrm{~m}$ long composite core from Lake Fúquene covers the last $284 \mathrm{ka}$ with $\sim 60$ years resolution. We address the various challenges and limitations of working with deep continental cores. For the tropics, the presence of these deep cores has made the Northern Andes a key area in developing and testing hypotheses in the fields of ecology, paleobiogeography, and climate change. We summarize the results in the figures, and for details on the paleoenvironmental reconstructions, we refer to the corresponding literature. We provide an overview of the literature on long continental records from all continents (see the Supplement). Based on our 50 years of experience in continental core drilling, developing a research capacity to analyze the large amounts of samples, and keeping a team together to publish the results, we listed suggestions in support of deep continental records aimed at studying environmental and climate change over long intervals of time.
\end{abstract}

\section{Introduction}

Our understanding of past climate change at Quaternary timescales has mainly been fueled by records from deep seafloor sediments (e.g., Tiedeman et al., 1994) and the Greenland and Antarctic ice sheets (Andersen et al., 2004; Dansgaard et al., 1982). The coring of the Greenland ice sheet was initiated by the International Geophysical Year 1957-1958. The first deep ice core at Camp Century dur- ing 1963-1966 reached the bedrock at $1388 \mathrm{~m}$ (Dansgaard et al., 1969). Marine sediments were explored in the frame of the Deep Sea Drilling Project (DSDP), which started back in 1966 and was later continued under the names Ocean Drilling Program (ODP), Integrated Ocean Drilling Program (IODP), and International Ocean Discovery Program (IODP). Drilling and multi-proxy studies were organized by a consortia of research institutes, allowing a broad spectrum of proxy expertise and research capacity. High drilling costs 
demanded critical preparation and well-organized logistics of the projects. The seaboard scientists had little time to study the results before the data had to be deposited and made available in open-access repositories, stimulating the development of new and fast methodologies to study a large number of proxy samples. Drilling in international waters and on desolate ice sheets pushed the need for efficient site selection and sample handling and contrasts with the permit-rich procedures in continental drilling.

Large ancient lakes have been widely recognized as continental archives of long-term climatic and environmental changes. Deep drilling of terrestrial continental sediments started in the 1950s, but compared to drilling deep marine records, the number of long continental records lagged behind.

Traditionally, ecologists assumed high levels of climatic and environmental stability in tropical and Mediterranean ecosystems to explain their stunning biodiversity. The 1960s were characterized by research aimed at studying the past dynamics of these systems and became a decade of discovery. In Greece, the famous $195 \mathrm{~m}$ deep Tenaghi Philippon core was collected (Van der Hammen et al., 1965; Wijmstra, 1969). Pollen analysis needed 2 decades, and the main results were published between 1979 and 1987. In the 1990s, the age-depth model of this core was improved and a land-sea correlation consequently developed (Tzedakis et al., 1997, 2001, 2006). Together with the long continental records from the Padul Basin, Spain (Florschütz et al., 1971; Pons and Reille, 1988; Torres et al., 2020), and the Grande Pile (Woillard, 1978), and Les Échets in France (de Beaulieu and Reille, 1984), to Clear Lake (Adam et al., 1981) and Tule Lake (Adam et al., 1989) in the USA, the continental drilling scene was set. However, continental records spanning the last $\sim 50000$ years before present $(50 \mathrm{ka})$, with a reasonable to high temporal resolution, were still rare. Long continental records received attention at the 12th International Union for Quaternary Research (INQUA) Congress in Ottawa, Canada (Kukla, 1989). Although the symposium organizers (George Kukla and David Adam) did not clearly define what was meant with a long continental record, the presented records included oscillations of a glacial-interglacial rank, with dominant frequencies of 40 and $100 \mathrm{kyr}$, and oscillations of the interstadial-stadial rank. A reviewed and updated compilation of long pollen records of this kind is presented in Table S1 and File S2 in the Supplement, of which the longest $(>125 \mathrm{ka})$ are shown in Fig. 1.

The development of a continental counterpart of the IODP was driven by a lack of climate stratigraphical information to frame marine records into a terrestrial perspective, among other reasons. Of the few continental records existing at that time, datasets were not freely accessible to the international research community. The 1995 Workshop Continental Drilling for Paleoclimate Records in Potsdam collected expertise and formulated first recommendations (PAGES, 1996), and the International Continental Scientific Drilling
Program (ICDP) was inaugurated in 1996. The ICDP stipulations relied much on the drilling knowledge and experience of the IODP, e.g., a thorough scientific preparation of the drilling expeditions. Nevertheless, the preparation time for a successful drilling operation still varies between 3 and 8 years (https://www.icdp-online.org/home/, last access: 9 September 2021), and results from continental records suffer from slow data processing, such as the manual and timeconsuming analyses of biotic proxies such as pollen, diatoms, and phytoliths (Flenley, 1984, 1985). Extensive processing requirements of long records may take 10 to 15 years, which rarely is convenient for young scientists. Ideally, analyses of slow proxies should be combined with rapid grain size and geochemical analyses based on X-ray fluorescence (XRF) to obtain a series of results over the course of a long continental drilling project.

\section{Long continental records from the Northern Andes}

Sediment cores are preferably collected in areas where tectonic activity caused the subsidence of the basin floor, giving rise to uninterrupted lacustrine sedimentation. A Dutch professor, Thomas Van der Hammen, envisioned a high potential of the basin sediments of Bogotá ( $2550 \mathrm{~m}$ above sea level a.s.1.; Fig. 2) when the first deep sediment core was recovered in 1956 on the premises of the Colombian Geological Survey. As a geologist and palynologist, he anticipated that this basin might include an unprecedented record of vegetation and climate change in a tropical mountain setting. The surrounding mountains of Bogotá, representing several sections of the Miocene to early Pleistocene age, depicted pollen assemblages that reflected warmer conditions when these sediments were located at lower elevations. The increasingly lower temperatures shown by pollen assemblages of successively younger sediments suggested that mountain uplift had been taking place since the late Miocene times (Van der Hammen et al., 1973; Wijninga, 1996; Hooghiemstra et al., 2006). Later, exhumation histories were improved by paleoaltimetric estimates, using a range of modern techniques from different disciplines (Hoorn et al., 2010; RestrepoMoreno et al., 2019; Boschman, 2021).

Drilling boreholes for water supply occurred regularly around the basin, but raising a core of undisturbed sediments was a challenging endeavor. A first $30 \mathrm{~m}$ core (named CUX - Ciudad Universitaria-X) was drilled near the border of the ancient Lake Bogotá, followed in 1957 by a $195 \mathrm{~m}$ deep core (named CUY - Ciudad Universitaria-Y) reaching the bedrock (Van der Hammen, 1968). Although the record of CUY suffered from numerous hiatuses caused by water level fluctuations, the record convincingly revealed a sequence of glacial and interglacial cycles, the altitudinal migration of upper montane forest and páramo along the mountain slopes, and pollen taxa which made their first appearances during 


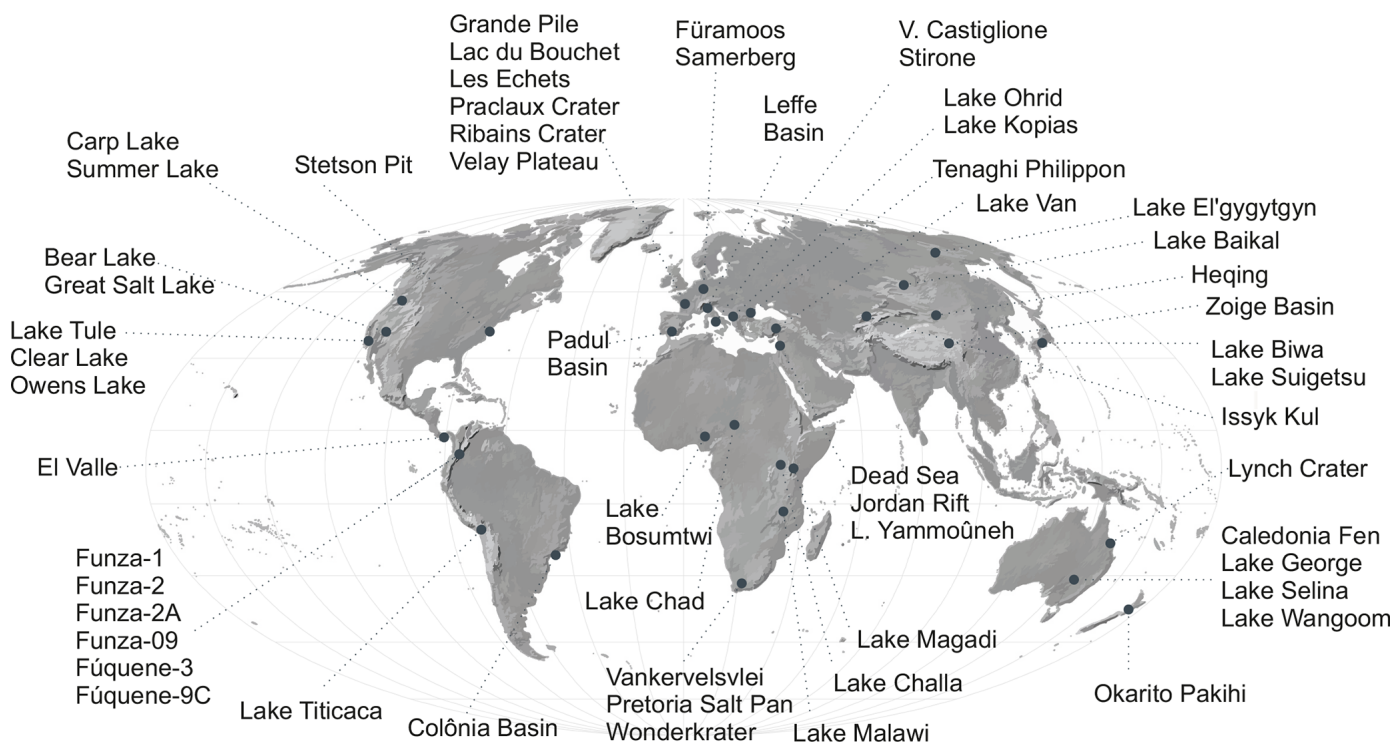

Figure 1. Global compilation of long continental fossil pollen records (> $125 \mathrm{ka}$ ). See also Table S1.

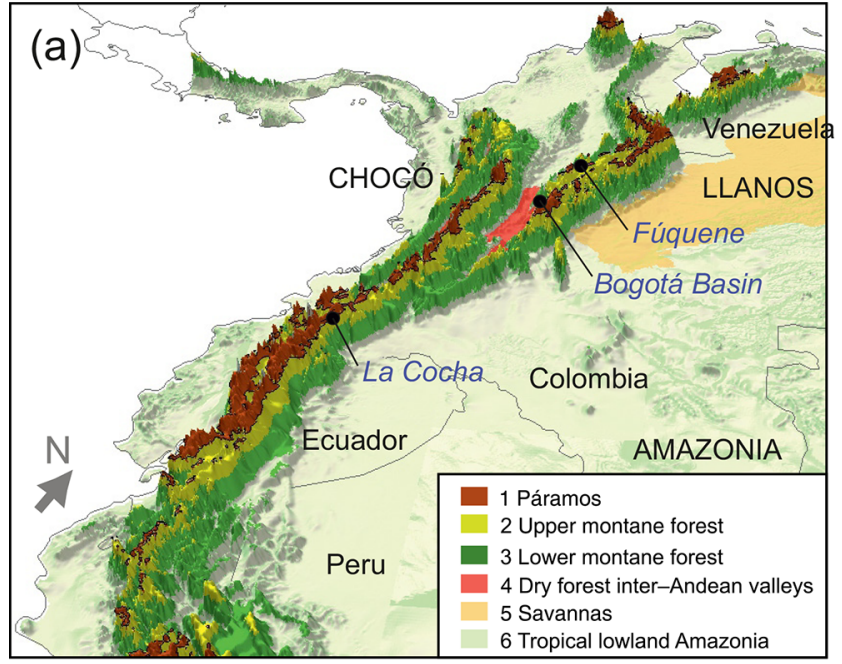

(c)

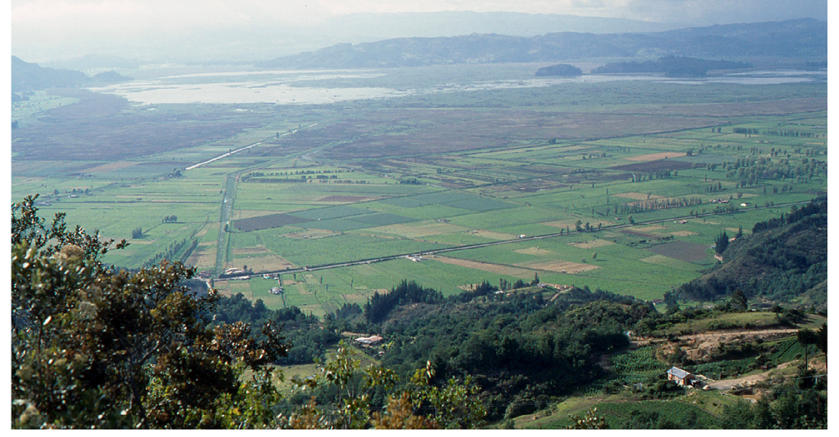

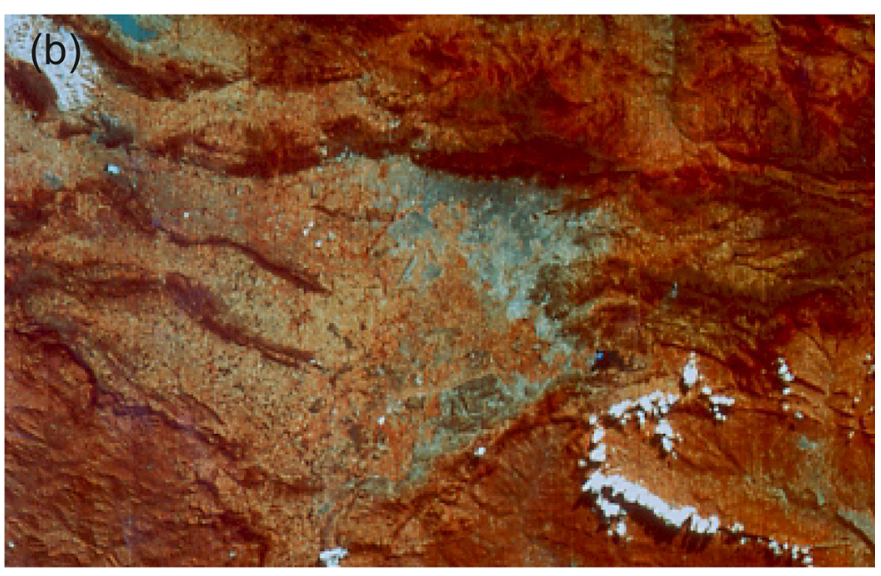

(d)

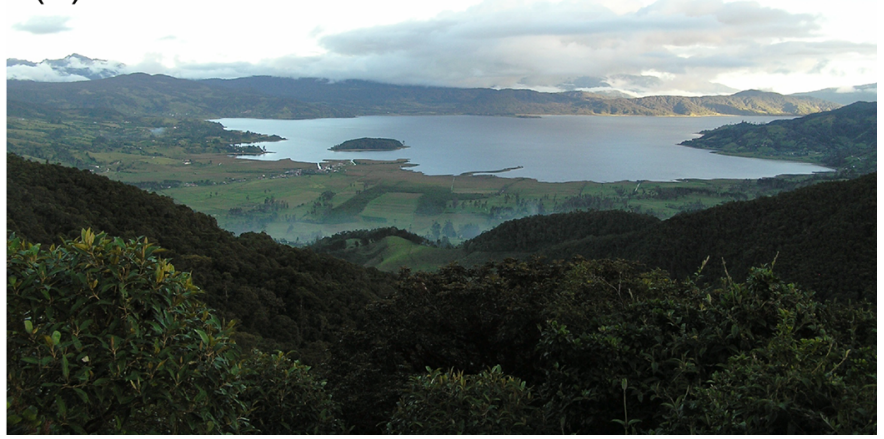

Figure 2. (a) Map of the Northern Andes showing the sedimentary basins discussed in the text. Photographs of the basins of Bogotá (b), Lake Fúquene (c), and Lake La Cocha (d). Figure supplied by Suzette G. A. Flantua). 

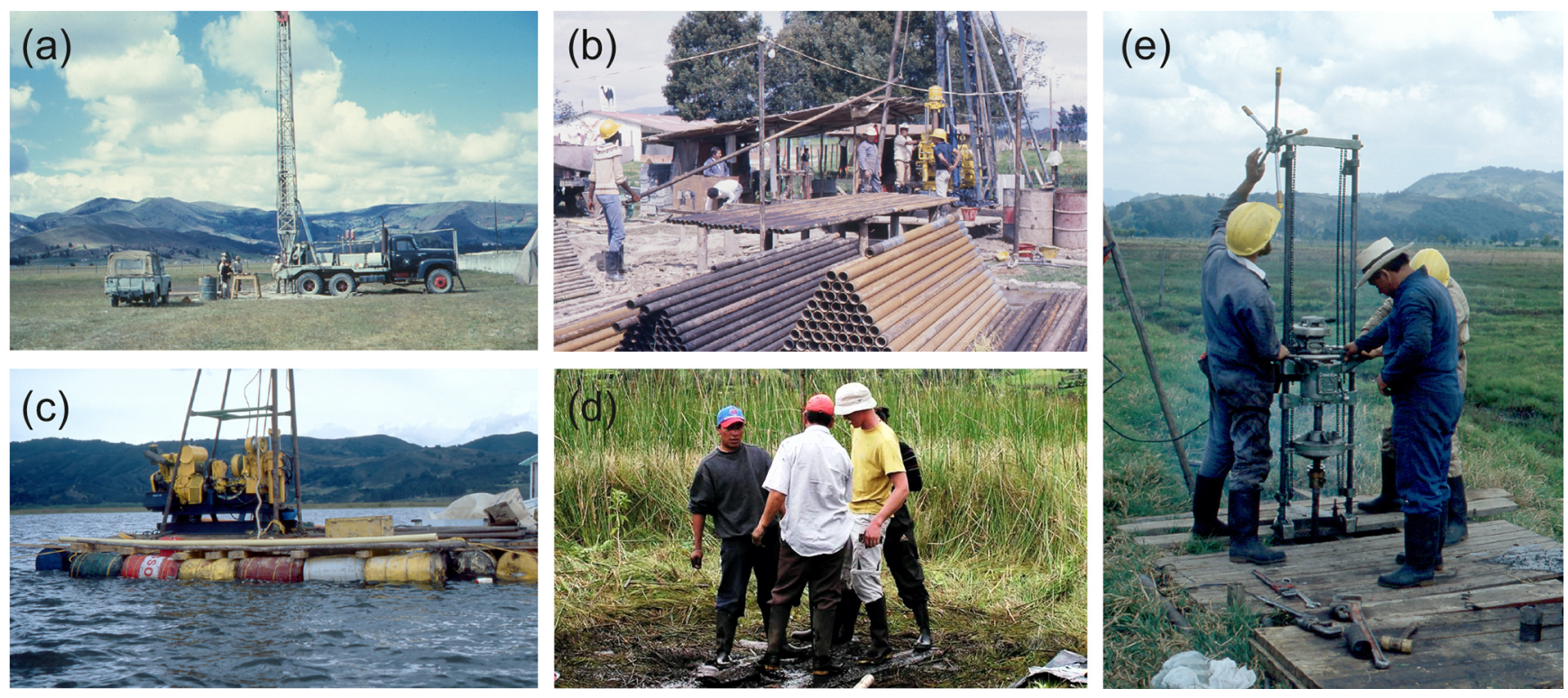

Figure 3. Photographs of the drilling sites at Funza 1 (a), Funza 2 (b), Fúquene 4 (c), La Cocha (d), and Fúquene 9 and 10 (e).

the Pleistocene (Van der Hammen, 1981). The CUY record formed the basis of a much-needed biostratigraphical framework for the Northern Andes. The enormous potential of the Bogotá sediments to uncover an unparalleled history of flora, vegetation, and climate in the tropics was convincing. These results stimulated the collection, in 1969, of the first $12 \mathrm{~m}$ core in Lake Fúquene (Van Geel and Van der Hammen, 1973), and in 1973, a subsequent core from the Bogotá basin near the village of Funza. The latter, the Funza 1 borehole, reached $357 \mathrm{~m}$ and was more centrally located in the basin, where geologists anticipated the deepest point until reaching the bedrock (Hooghiemstra, 1984; Fig. 3).

\section{Bogotá basin: Funza 1 record}

Fracking and faulting of continental plates in the Eastern Colombian Cordillera (Restrepo-Moreno et al., 2019) caused gradual subsidence during most part of the Quaternary period (Fig. 4). The initial fluvio-lacustrine conditions changed at $1.6 \times 10^{6}$ years before present $(1.6 \mathrm{Ma})$ into a permanent lake with water levels maximally up to $50 \mathrm{~m}$ (Hooghiemstra, 1984). The sediment infill of the basin is kept in equilibrium with subsidence, which explains the unique continuous sediment archive covering the last $2 \times 10^{6}$ years. The Bogotá River and its tributaries served as the main drainage system, with varying energy influx as documented by the silts, sands, and gravels along its courses, while, elsewhere in the basin, lacustrine conditions prevailed (Van der Hammen, 1998). The Funza 1 borehole consisted of intervals of coursegrained sediments that often carry subterraneous water flows, which cause severe technical problems when collecting sediments and regularly leave hiatuses in the sediment core or, even worse, prevent deeper coring.
The initial age-depth model of the Funza 1 pollen record was problematic and based on the fission track and uraniumthorium (U-Th) dates of intercalated volcanic ashes with large uncertainties of the order of 300 to $500 \mathrm{kyr}$. To set a chronological time frame to the record, the European climate stratigraphy was used for reference, as other dating approaches were unavailable at that time (Zagwijn, 1960; Van der Hammen et al., 1971). Originally, the Funza 1 record was thought to be $3.5 \mathrm{Ma}$ (Hooghiemstra 1984), but an updated revision of the age model dated the basis at $\sim 1.5 \mathrm{Ma}$ (Torres et al., 2013). The detailed record of glacial-interglacial cycles and the altitudinal dynamics of Andean ecosystems was unprecedented. The record witnessed the first appearance of Alnus and Quercus that became important biostratigraphical markers as evidence of immigration of Northern Hemisphere arboreal taxa into the Northern Andes and the South American continent. It was estimated that, in response to the Quaternary climate fluctuations, the upper forest line migrated between $\sim 2000$ and $\sim 3500 \mathrm{~m}$ a.s.l., reflecting a temperature amplitude of $\sim 9^{\circ} \mathrm{C}$ at $2550 \mathrm{~m}$ a.s.l. characteristic of the lowest glacial temperatures of the last $1 \mathrm{Ma}$. An average 1200 -year resolution showed the asymmetry of glacial cycles, the continuous altitudinal shifts of vegetation distributions and inherent temperature oscillations reflecting stadialinterstadial cycles, and temperature related cycles in the lakelevel record.

\section{Bogotá basin: Funza 2 and Funza 2A records}

Coring at Funza 1, unfortunately, failed to reach the basin floor, the age model was insufficiently constrained, and grain size analysis was missing to understand how sediment infill had taken place. After a postdoctoral period in Göttingen, 
(a)

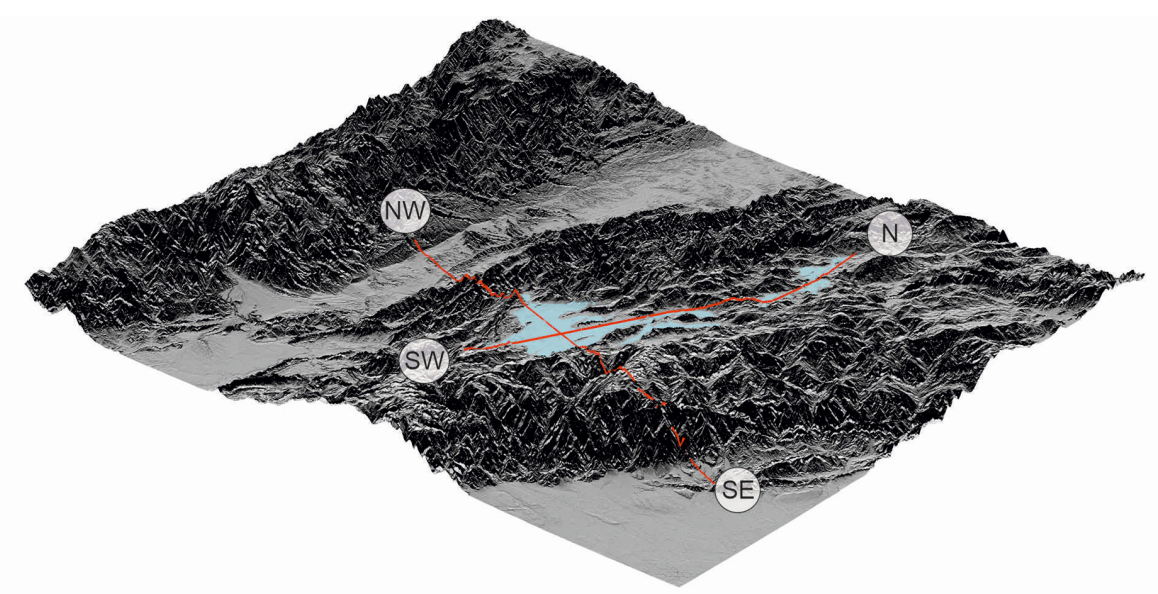

(b)

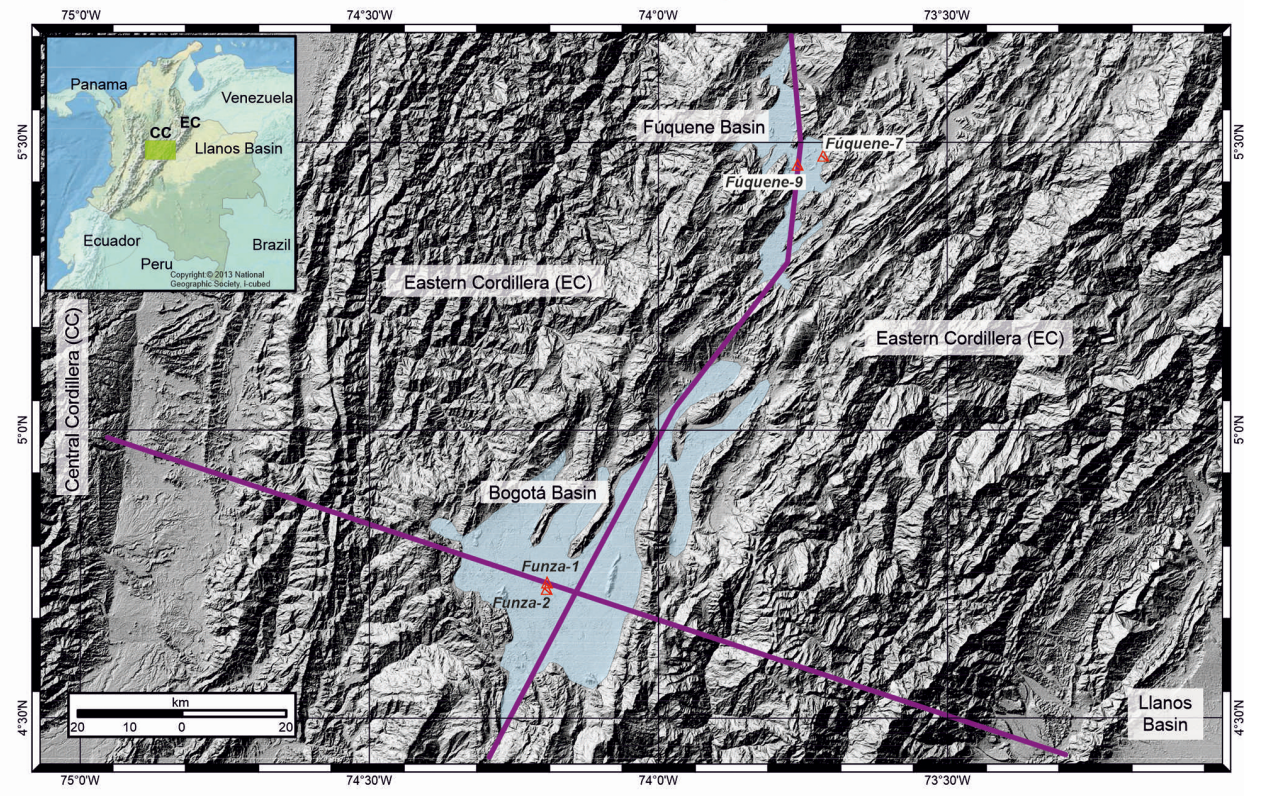

(c)
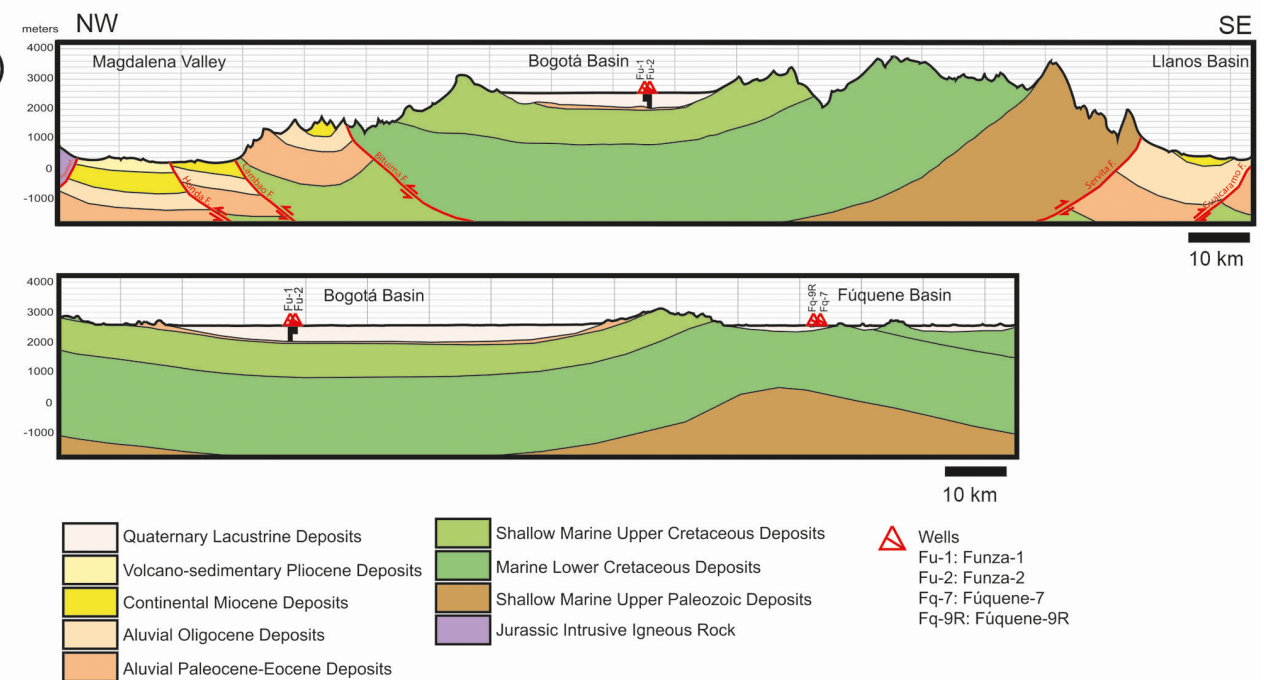

$\Delta$ Wells

Fu-1: Funza-1

Fu-2: Funza-2

Fq-7: Fúquene-7

Fq-9R: Fuquene-9R

Figure 4. Cross section (a) and top view (b) of the Bogotá basin at $2550 \mathrm{~m}$ a.s.l. (above sea level) in the Eastern Cordillera, Colombia. During the early Quaternary, an accelerated subsidence of the basin floor gave rise to the development of the ancient Lake Bogotá. The lower sediment infill contains gravels, sands, silty clays, and lignite horizons. The middle and upper part of the sediments are lacustrine silts and clays. (c) Tentative cross section of the basin of Lake Fúquene; the thickness of the sediment accumulation is unknown (figure by Gustavo Sarmiento Pérez). 
Germany, studying marine cores off the coast of northwestern Africa, Dutch paleoecologist Henry Hooghiemstra (lead author) returned to Amsterdam in 1987, where Thomas van der Hammen was based, and started a new coring project to reach the floor of the Bogotá basin. As the required permissions for deep-core drilling made the choice of sites limited, Funza 2 was drilled in the backyard of a school located at ca. $1 \mathrm{~km}$ distance from Funza 1 and ca. $50 \mathrm{~m}$ from a tributary of the Bogotá River. Subterraneous water under high pressure again imposed challenges and prevented the recovery of the 160-205 m interval, and consequently, a complete sediment sequence could not be collected. Funza 1 sediments were used to fill the hiatus of the Funza 2 record at this depth interval. Drilling rods of 3 in. $(76.2 \mathrm{~mm}$; 0 $320 \mathrm{~m}), 2$ in. (50.8 mm; $320-370 \mathrm{~m})$, and $1.5 \mathrm{in} .(38.1 \mathrm{~mm}$; below $370 \mathrm{~m}$ ) diameter were used, while the casing of the borehole reached up to $380 \mathrm{~m}$ core depth. The lowermost $200 \mathrm{~m}$ of the borehole was stabilized with bentonite only, and collecting these deepest sediments consumed most of the 5week drilling operation. At $586 \mathrm{~m}$ core depth, the sampler touched the bedrock and, thus, the floor of the Bogotá basin. The sudden change to drilling in hard rock caused a break in the drilling rods at $\sim 250 \mathrm{~m}$ above the basin floor. The sampler, including the last sediments collected, and some $250 \mathrm{~m}$ of drilling rods were lost and now form an eternal testimony in the deepest sediments of the basin.

Dating the intercalated volcanic ash horizons for the agedepth model was again challenging, as these were heavily contaminated with lacustrine clays. The fine-grained ashes originated from the volcanic Central Cordillera were windblown into the Eastern Cordillera, where no volcanoes are present. The chronological uncertainty of the 1984 agedepth model of Funza 1 was replicated in the 1993 age-depth model of Funza 1 and 2 (Andriessen et al., 1993). To circumvent the poor quality of the absolute chronological control, a frequency analysis of the records of selected pollen taxa showed to which degree orbital forcing was potentially a driver of climate and vegetation change (Hooghiemstra et al., 1993).

In the period 1993 to 2002, little progress was made in the Funza project, as funding had ended. With new funding obtained in 2002, pollen analysis of the lower part of core Funza 2 was completed by Vladimir Torres Torres during the 4 following years. A grain size analysis provided insights into the sedimentary environment on the basin floor (Torres et al., 2005). Still, the existing age-depth model was deficient at that moment (Torres Torres, 2006) due to insufficient absolute age control and unfinished analysis of signals of orbital forcing. The age-depth model of the Bogotá sediments received new attention in the frame of the Fúquene Project (running from 2002 to 2012). The most reliable parts of the two Funza records, namely the $2-256 \mathrm{~m}$ interval from Funza 1 and the 254-586 m interval from Funza 2, were merged into the composite pollen record Funza 09 (Fig. 5). The final age-depth model was obtained using the ${ }^{14} \mathrm{C}$ ages from the top of the record, a curve matching procedure with marine $\delta^{18} \mathrm{O}$ records of sites ODP 846 and 849 for the upper $1 \mathrm{Ma}$, and orbital tuning for the lowermost part of the record based on arboreal pollen fluctuations (Torres et al., 2013).

The sediment record appeared extremely helpful in understanding the history of the sedimentary basin. The change from forested wetlands, lakes, and rivers on the floor of the Bogotá basin to the permanent lake conditions (Torres et al., 2013) evidenced the accelerated subsidence of the basin floor at 1.4 Ma, leading to the birth of the ancient Lake Bogotá. The composite record extended the vegetation and climate history back to $2.25 \mathrm{Ma}$, whereas the sediment record possibly covers almost the complete Quaternary period (Vladimir Torres Torres and Henry Hooghiemstra, unpublished data). The immigration events of Alnus and Quercus were definitively set at $1.01 \mathrm{Ma}$ and $430 \mathrm{ka}$, respectively (Torres et al., 2013), clearly illustrating the difference in latitudinal migration and regional (altitudinal) expansion capacities between the pioneer Alnus and the late successional tree Quercus. To date, the Funza 2A record (Mommersteeg, 1998) still needs a revision of its age-depth model.

\section{Records from Lake Fúquene}

The drainage basin of Lake Fúquene is separated from the basin of Bogotá by a water divide at $3200 \mathrm{~m}$. The basin of Lake Fúquene most probably received its sediment infill after a landslide in the narrow drainage outlet of the valley north of the current lake. Behind the colluvial dam, the proximal part of the valley developed into a wetland that served as a plug to keep a water body in the distal (southern) part of the valley, where Lake Fúquene is now located. A ridge of Cretaceous sandstone forms a constriction between the proximal and distal parts of the basin, stabilizing its sediment infill (Figs. 2, 3; Sarmiento et al., 2008). The maximum thickness of the sediments in Lake Fúquene is still unknown. A $12 \mathrm{~m}$ core obtained from the swamps along the eastern border produced a $\sim 35 \mathrm{ka}$ long record (Van Geel and Van der Hammen, 1973). A follow-up core up to $14 \mathrm{~m}$ depth (Fúquene 7) was obtained in 1994, where soft sediments prevailed. Deeper sediments (13-18 m interval) were collected at $7.5 \mathrm{~m}$ distance, with drilling equipment stabilized on top of a small dike (Fúquene 4). In total, eight radiocarbon-dated samples varying between 38400 and $6040{ }^{14} \mathrm{C}$ years BP suggested that the 17.7-2.8 $\mathrm{m}$ interval of composite record Fúquene 7C reflects the period between ca. 88 and $6 \mathrm{ka}$ (Mommersteeg, 1998).

In 1999, the lead author participated in the European Research Conference on Polar Regions and Quaternary Climate in Giens (France). This conference inspired him to increase the temporal resolution of pollen records in the Northern Andes by an order of magnitude to reveal the vegetational and climatic changes up to better-than-century-scale detail within a glacial-interglacial cycle. The $43 \mathrm{~m}$ long pollen record, 

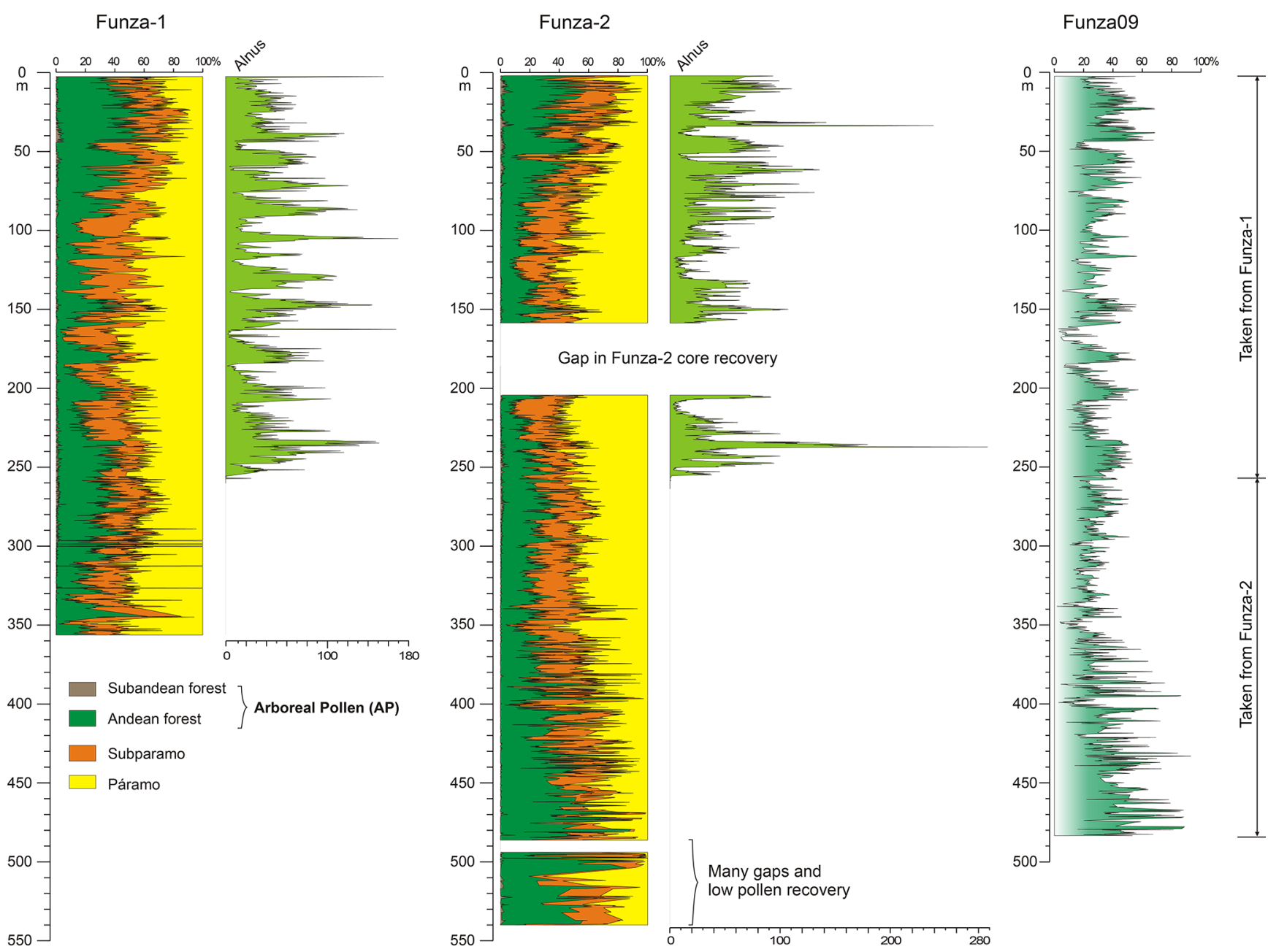

Figure 5. Stacked pollen records of Funza 1 and 2 and the composite record of Funza 09 showing changing percentages of four altitudinal vegetation belts. Alnus is excluded from the pollen sum (records are separately shown) and mainly reflects changes in surface area of Alnusdominated swamp forest driven by lake-level changes. The Bogotá basin lies halfway between the lowermost and uppermost position of the upper forest line and makes the record of Alnus a sensitive recorder of glacial-interglacial cycles.

Fúquene 3, was estimated to reach $\sim 125 \mathrm{ka}$, thus ending close to the last interglacial (Eemian), corresponding to the Marine Isotope Stage 5e (MIS 5e; Van der Hammen and Hooghiemstra, 2003). It was decided to core up to $\sim 60 \mathrm{~m}$ to be sure to sample the complete MIS 5. A total of two parallel cores (Fúquene 9 and Fúquene 10) were drilled from a floating platform by a commercially hired drilling company (Fig. 3), recovering sediments from $1.5-58 \mathrm{~m}$ below the lake floor. During the drilling operation, heavy rains increased the water depth significantly, and the drilling halted when methane gas suddenly escaped from the drilling hole and continued to do so for about $15 \mathrm{~h}$. Later on, it became clear that peat layers of Eemian age at $22 \mathrm{~m}$ core depth had degassed to such an extent that it had caused a $60 \mathrm{~cm}$ lowering of the lake floor around the drilling location.

The successfully obtained 115 core intervals of $100 \mathrm{~cm}$ length and $8 \mathrm{~cm}$ diameter were subsequently transported by airfreight. Diplomatic protection allowed the cores to arrive undamaged and unopened in the Netherlands. The cores were cut into a sampling half and a museum half and photographed (Fig. 6). Subsequently, the sediment cores were analyzed with an X-ray fluorescence (XRF) scanner at $1 \mathrm{~cm}$ distance, and 46 samples were radiocarbon dated. Based on lithology and XRF stratigraphy from both parallel cores, one single composite core, Fúquene 9C, was constructed (Groot et al., 2011). Subsequently, along the composite core at $1 \mathrm{~cm}$ sample distance, grain size distributions and fossil pollen were analyzed (Bogotá-A et al., 2015; Groot et al., 2013). The preparation capacity of the pollen laboratory in Amsterdam was consequently upscaled. There were two Amsterdambased doctoral students assisted by five well-trained pollen analysts working at the Universidad Nacional in Bogotá, Colombia. Unfortunately, the $46{ }^{14} \mathrm{C}$ ages were inconclusive for various reasons (Groot et al., 2014). The final age- 
depth model was based on nine ${ }^{14} \mathrm{C}$ radiocarbon ages at the top, while an orbital tuning approach provided 13 calibration points based on the detected $41 \mathrm{kyr}$ obliquity forcing signal (Groot et al., 2011). The final 4138 sample pollen record was dated to cover 284 to $27 \mathrm{kyr}$ and reflects an average resolution of 62 years (Fig. 7). The rapid proxies (XRF and GSDs grain size distributions) provided a stratigraphical framework within a year (Vriend et al., 2012). This project showed, for the first time and with unprecedented precision, the high degree of climate-change-driven dynamics in vegetation distribution, floral composition, and ecological characteristics as experienced by tropical ecosystems, i.e., the anatomy of an ice age cycle in a tropical mountain setting (Bogotá-A et al., 2011, 2015; Groot et al., 2011, 2014).

There is much speculation with respect to why the sedimentary record in the central part of Lake Fúquene stopped at $27 \mathrm{ka}$. Remarkably enough, the sediment accumulation also ceased around the same time in the nearby Bogotá basin. An optional explanation is that sediment accumulation in both basins was disturbed by a regional tectonic event. Another plausible hypothesis is that the Bogotá basin overfilled with sediment, and at Lake Fúquene, a change in the water current from an eastern trajectory to a more centrally located trajectory in the lake basin locally prevented further sediment accumulation. These issues are unresolvable with the current understanding of the sedimentary stratigraphies lacking geophysical surveys such as gamma ray logs, resistivity logs, sonic logs, or seismic logs. The massive research investment in the Bogotá basin and Lake Fúquene in the Colombian Andes had still left the Holocene unstudied in sufficient detail. This observation motivated us to core Lake La Cocha to develop a high-resolution Holocene record.

\section{Lake La Cocha basin}

In 2004, a swamp area at the border of Lake La Cocha (2780 ma.s.1.) was cored up to $12 \mathrm{~m}$ depth with a handoperated Russian corer. Sediments were sampled for pollen, charcoal, diatoms, and ${ }^{14} \mathrm{C}$ dating. The age-depth model was based on $18{ }^{14} \mathrm{C}$ samples, and the record reflects the last 14 kyr (González-Carranza et al., 2012). With 550 pollen samples analyzed, the record shows vegetation dynamics at an average resolution of 27 years. The record shows a $7 \mathrm{kyr}$ long trend, from 9 to $2 \mathrm{ka}$, of an increasing share of arboreal pollen, reflecting the increasing temperature at the start of the Holocene and an increase in precipitation due to the southward migration of the ITCZ (Intertropical Convergence Zone) during that time interval. From ca. $8 \mathrm{ka}$ onwards, the record of arboreal vs. herbaceous vegetation shows centennial-scale oscillations hinting to the start of the El Niño-Southern Oscillation (ENSO). Climate-driven and internal forest dynamics are evidenced by a suite of nonanalogue forest associations that are different from today.

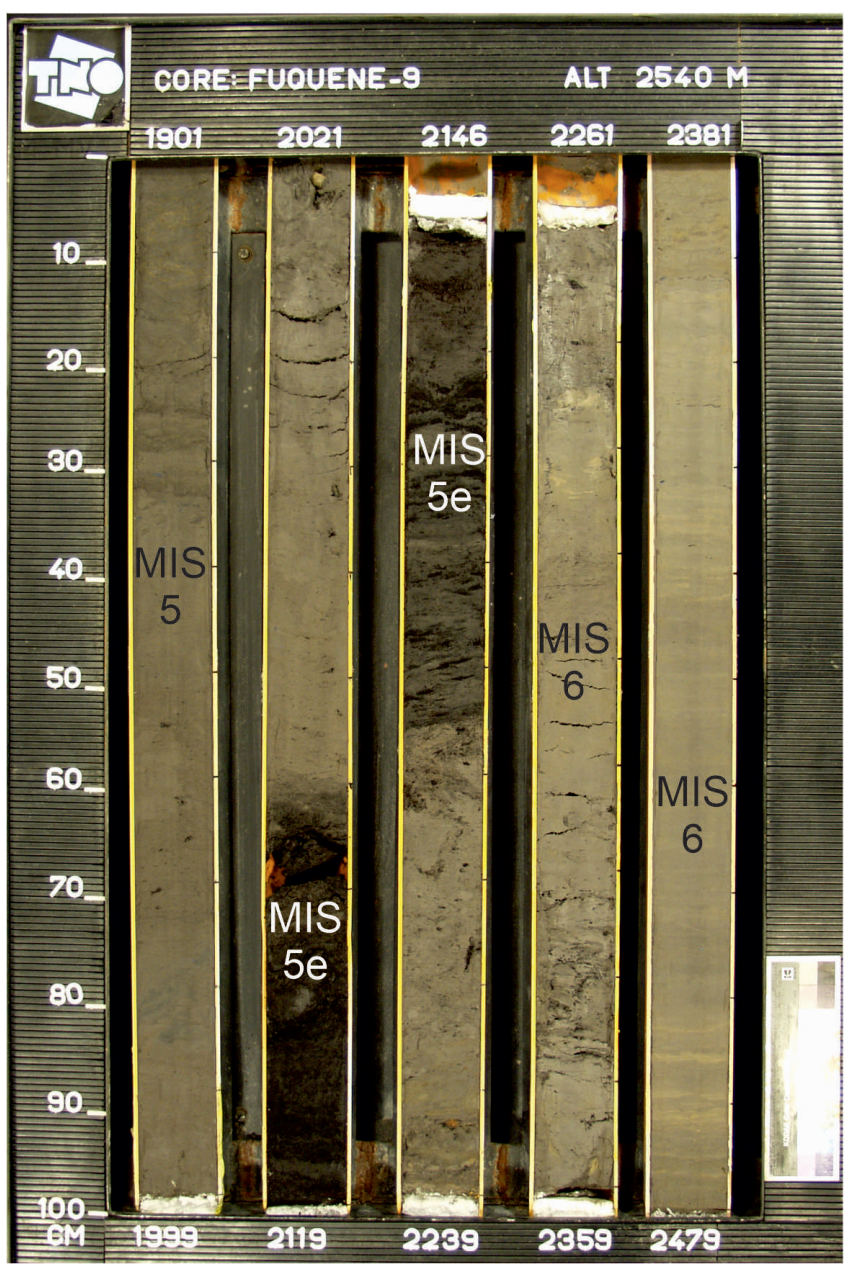

Figure 6. Lithological sequence of the $1901-2479 \mathrm{~cm}$ interval of core Fúquene 9, reflecting approximately the period from 118 to $135 \mathrm{ka}$. Almost laminated glacial silty clays (2479-2200 cm; MIS 6) change into dark organic rich sediments $(2190-2090 \mathrm{~cm})$, reflecting the compressed peat of the last interglacial (MIS 5e) age and indicating that low water tables prevailed. The younger part of MIS 5 was cooler (less evaporation), with higher lake levels explaining the accumulation of silty clays $(2080-1900 \mathrm{~cm})$. Cores 9 and 10 were lined up using XRF-based geochemical records, as shown in Groot et al. (2011). Composite pollen record of Fúquene 9C mainly consists of Fúquene 9 sediments. At intervals where core Fúquene 10 provided a more reliable stratigraphy, small intervals of core 9 were replaced by core 10 . Photograph courtesy of TNO Core Laboratory, Utrecht, The Netherlands.

The last $1.4 \mathrm{kyr}$ of the record show significant evidence of human impact through deforestation.

The relevance and added value of high-resolution pollen analyses in long continental records has been widely debated. Opinions may be driven by the required large investment in research time. So far, efforts of automated pollen counting have not resulted in a feasible methodology (France et al., 2000). Here, we compare the La Cocha pollen record plotted at a commonly used $\sim 210$-year resolution $(16 \mathrm{~cm}$ sam- 

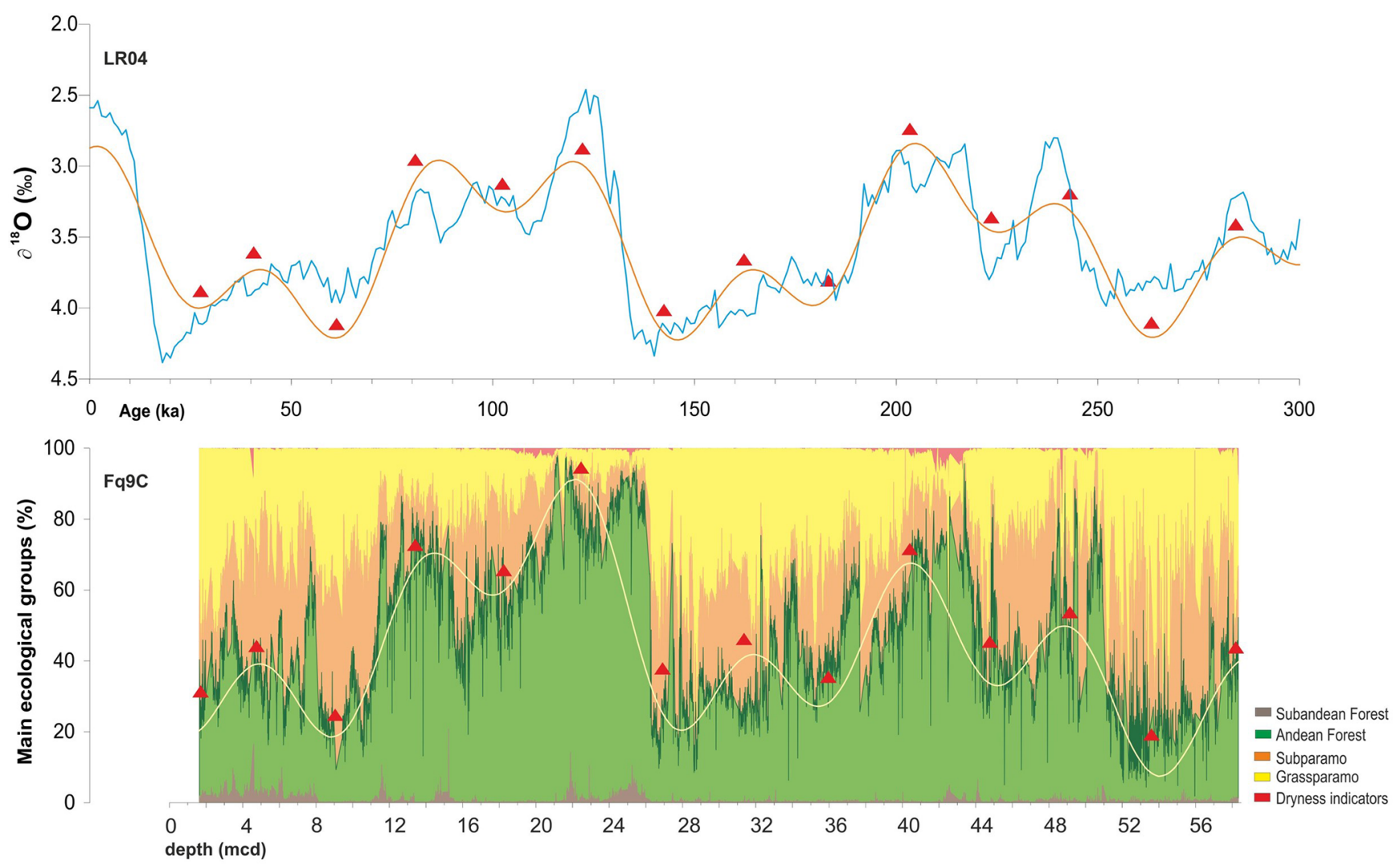

Figure 7. Pollen record of Lake Fúquene 9C (2540 m a.s.1.) plotted on a linear depth scale (3-58 $\mathrm{m}$ core interval). The records show the vegetation change through time in 4138 samples. Changing proportions between montane forest (green) and treeless páramo (orange shrubs; yellow - herbs) reflect the altitudinal shifts in the mainly temperature-driven upper forest line. The oxygen isotope record LR04 (Lisiecki and Raymo, 2005) is plotted on a linear timescale. In both records, the $41 \mathrm{kyr}$ obliquity forcing is evident (orange line). Control points (red triangles) show the correlation between the records (for details and age model development, see Groot et al., 2011).

ple distance) with a high-resolution sample distance of $2 \mathrm{~cm}$ (ca. 27-year resolution; Fig. 8; González et al., unpublished data). In the high-resolution record, the emergence of centennial climate variability becomes obvious and can provide crucial insights for comparison with high-resolution proxies, e.g., stalagmites from cave records. Importantly, information in high-resolution pollen records can support observations in ecological studies that include time series covering the last 50 years (Chacón-Moreno et al., 2021).

Developing a link between current and past ecosystem dynamics has high relevance for exploring operating mechanisms and developing a societally relevant understanding. For instance, several rapid warming events in this record show that montane forest near the upper forest line can shift upslope very fast. The cool subpáramo above the upper forest line was at times unable to respond at the same speed, resulting in a temporal disappearance as a consequence (GonzálezCarranza et al., 2012). Due to habitat connectivity with other locations where subpáramo occurred (Flantua et al., 2014), this vegetation type returned within a few centuries, showing that the loss of an elevational belt with subpáramo shrub was a temporary effect.

\section{Long continental records globally and in the Andes: conclusions and perspectives}

The late 1950s, a decade before the official start of IODP in 1966, saw an exciting start of deep scientific drilling in the marine, continental, and ice sheet archives. It was the start of unveiling the long series of ice ages that characterized the Quaternary period and a much better understanding of time by the discovery of radiocarbon dating (Libby et al., 1949) and the development of the oxygen isotope stratigraphy (Emiliani 1957, 1966, 1970, Shackleton, 1987). In marine sediment cores, the start of the Quaternary was based on the change in paleomagnetism, reflecting the BrunhesMatuyama paleomagnetic reversal dated at $1.66 \mathrm{Ma}$. However, continental evidence showed $\sim 2.5 \mathrm{Ma}$ as a logical start of the Quaternary, with a first ice age of significant cooling (Zagwijn, 1960, 1992), which caused controversial opinions and debates on the beginning of the Quaternary in the paleoecological community. The debate between proxies continued for half a century (see also Hooghiemstra and Hoek, 2019), but terrestrial arguments eventually provided conclusive evi- 

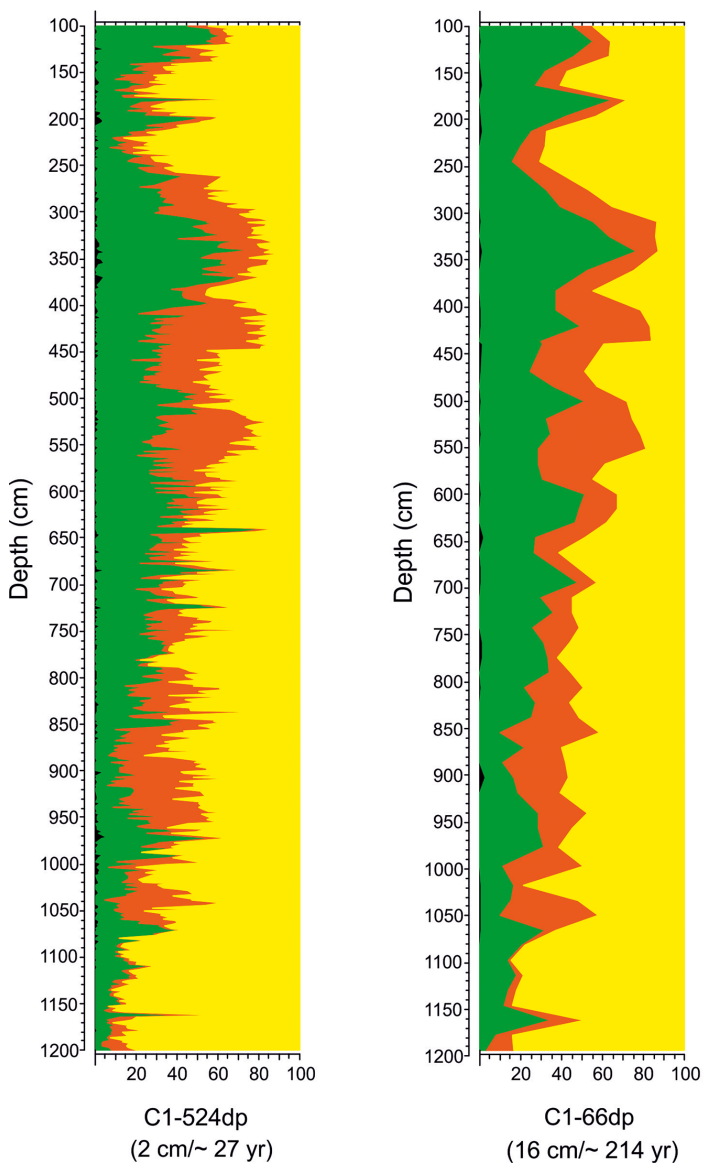

Lower montane forest

Upper monatane forest

Subpáramo

Grass páramo

Figure 8. Pollen record from Lake La Cocha 1 (2780 m a.s.1.; $12 \mathrm{~m}$ long core) shows climate-driven altitudinal shifts of the main vegetation belts during the last $14 \mathrm{kyr}$. Vegetation change is shown at $16 \mathrm{~cm}$ sample distance (reflecting a $\sim 210$-year resolution) and at $2 \mathrm{~cm}$ sample distance (reflecting a $\sim 27$-year resolution). Centennial-scale climate oscillations are evident at high resolution (figure courtesy of Zaire González Carranza).

dence for the start of the Quaternary at 2.59 Ma (Gibbard et al., 2010).

Marine and ice core drilling projects developed rapidly into research consortia of global relevance. Paleoclimate research based on continental drilling continued mainly as a curiosity-satisfying enterprise driven by single persons. However, with an increasing number of high-quality marine and ice core records, it became tantalizing to see how continental ecosystems had survived Quaternary climate dynamics and the tropical ecosystems in particular (Hooghiemstra and Flantua, 2019; Hooghiemstra and Van der Hammen, 2004). The foundation of an ICDP in 1996 was a logical step. ICDP requirements were rooted in the long and professional experience of its marine counterpart IODP. As a result, deep continental drilling became rapidly professionalized and replaced low-budget projects.

In this paper, experiences of half a century of deep continental drilling in the Northern Andes are brought together, serving new initiatives within and beyond ICDP-framed studies (see File S3). The main message is that deep con- tinental drilling is optimally served by high-tech ICDP coring facilities. However, national geological surveys may potentially offer alternative possibilities to raise deep undisturbed sediment cores for past climate research. Obtaining a good quality long sediment core is a prerequisite, but practice shows that analyzing the huge amounts of samples, developing sound age-depth models, and writing research papers before team members at the end of a project are radiating into different directions and is even more challenging. While marine and ice core studies reflect the Earth's dynamics in uninhabited parts of the world, long continental records may be retrieved from densely populated areas, providing a record of how the environment of humans has changed over longer timescales. Revisiting earlier studied sedimentary basins might be attractive when new methods have become available. The quality of a recovered sediment core, the variety of proxies analyzed, and the temporal resolution of sampling may substantially improve. However, when revisiting basins, the balance between available understanding and additions to be expected must be carefully considered. 

$\checkmark$ Occasional sky islands $\bigodot$ Fragmentation
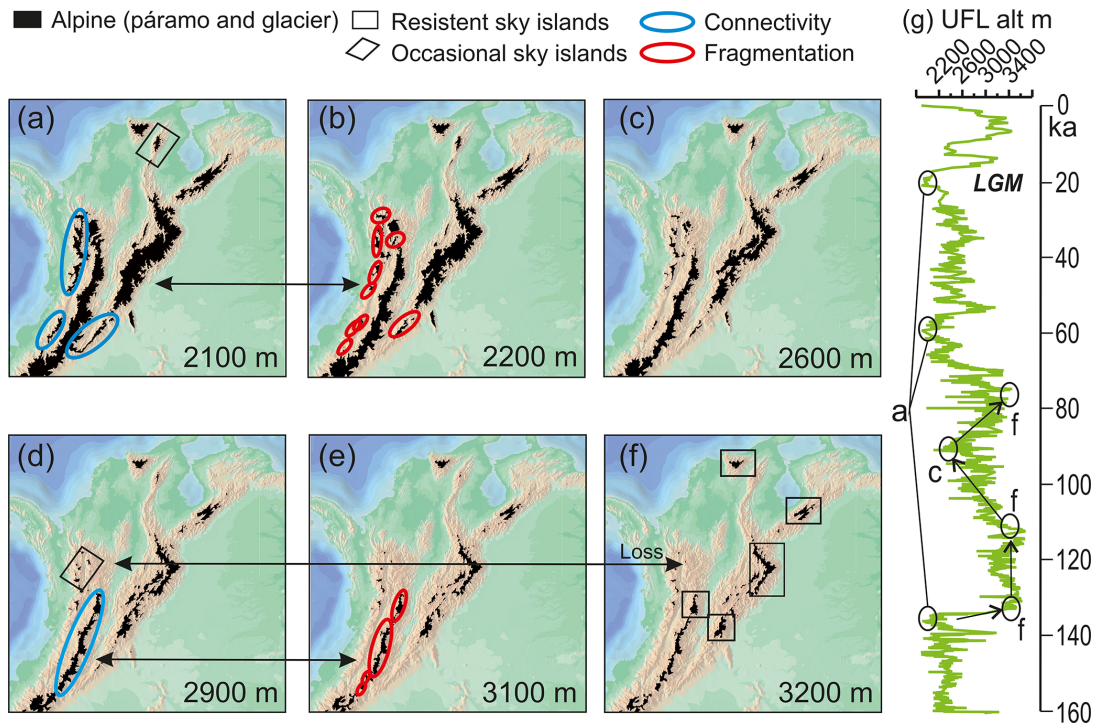

Figure 9. The $160 \mathrm{ka}$ interval of composite pollen record of Fúquene 9C (g), showing that the upper forest line (UFL) positions varied between 2000 and $3200 \mathrm{~m}$ (a-f). Using UFL positions as input for a digital elevation model, simplified maps of the spatial distribution of páramo vegetation were reconstructed (Flantua and Hooghiemstra, 2018). In the Northern Andes, páramo distribution varied between a glacial maximum extension (UFL at $2000 \mathrm{~m}$ ) and an interglacial minimum extension (UFL at $3200 \mathrm{~m}$ ). During periods of increased temperatures (at the frequent stadial-interstadial transitions and during the few glacial-interglacial transitions), the distribution of páramo vegetation shows marked events of fragmentation in the Western Cordillera (UFL at $2200 \mathrm{~m}$ ), Venezuelan Cordillera (UFL at $2600 \mathrm{~m}$ ), Eastern Cordillera (UFL at $2900 \mathrm{~m}$ ), and Central Cordillera (UFL at $3100 \mathrm{~m}$ ), depending on the mountain-specific profile or mountain fingerprint (Flantua and Hooghiemstra, 2018; Flantua et al., 2019). Long continental pollen records serve a new field of research and hypothesis testing for different disciplines.

Archiving terrestrial sediment cores depends on the institutional facilities and is another hurdle in revisiting existing cores in good condition.

We are at the start of developing an understanding of the spatial dynamics of mountain ecosystems in which long continental records play a crucial role. For instance, superimposing the shifting altitudinal position of the upper forest line of the last $1 \times 10^{6}$ years on a digital elevation model of the Northern Andes allowed new insights into the consequences of temporal change on spatial changes of forest and páramo dynamics (Flantua et al., 2014; Flantua and Hooghiemstra, 2018; Flantua et al., 2019) (Fig. 9). Such new approaches open and stimulate a new field of ecological and paleobiogeographical research questions to be assessed, and long continental records from tropical mountain areas play a new role in understanding Quaternary environmental dynamics.

Marine sediments and ice caps have proven to be unparalleled archives to boost our understanding of environmental and climatic change. High-resolution long continental records meticulously show the changes in environments where significant parts of the world's population live. Although continental drilling requires loads of national and international permits, ICDP serves a societal and scientific relevance to help humankind be guided to its future. To support the dissemination of current understanding on how Quaternary environmental and climate dynamics have driven biodiversity in mountain areas to high levels, we provide a visualization (https://www.youtube.com/watch?v= -Wcp18vBDK4, last access: 2 February 2022). The clues to the future are in the past.

Data availability. Visit https://www.latinamericapollendb.com/ (last access: 2 February 2022, Flantua, 2022) for an overview of modern and fossil pollen sequences in Latin America, as reviewed by Flantua et al. (2015). Raw pollen counts of the Latin American Pollen Database (LAPD) can be obtained from the Neotoma Paleoecology Database (https://www.neotomadb.org/, last access: 2 February 2022; Williams et al., 2018). Visit https://www2.le.ac.uk/departments/geography/people/jcb34 (last access: 2 February 2022, Berrío and Hooghiemstra, 2022) for data from Fúquene 09.

Video supplement. Visit https://figshare.com/articles/ Appendix_6_Visualization_of_the_flickering_connectivity_ system_in_the_Northern_Andes/7408643 (Giraldo et al., 2022) for a visualization of a current understanding of the Pleistocene environmental and climate dynamics in the Northern Andes.

Supplement. Table S1 shows a list of the Quaternary long continental pollen records, with a special focus on sediment cores drilled before the initiation of the International Continental Scien- 
tific Drilling Program (ICDP) in 1996. The term "long record" is not precisely defined here. The current list is the result of a review of the literature. Specific information of the cores is provided. References are found in File S2. Supplement 2 shows the list of references for Table S1. Supplement 3 has recommendations for developing long continental pollen records based on experience from the Northern Andes. The supplement related to this article is available online at: https://doi.org/10.5194/sd-30-1-2022-supplement.

Author contributions. HH designed and wrote the paper. All authors contributed equally to the text. The sequence of the first four authors (HH, GSP, VTT, and JCB) reflects their chronological contribution to developing long continental pollen records in Colombia, while SGAF transformed our understanding of the past from a temporal into a spatial scale. GSP and SGAF developed the illustrations. LL developed the age-depth models.

Competing interests. The contact author has declared that neither they nor their co-authors have any competing interests.

Disclaimer. Publisher's note: Copernicus Publications remains neutral with regard to jurisdictional claims in published maps and institutional affiliations.

Acknowledgements. Thomas van der Hammen (deceased) initiated and explored scientific drilling in the Colombian basins. We thank the Colombian Geological Survey (currently Servicio Geológico Colombiano) of Bogotá, Colombia, for supporting drilling activities. We thank the Instituto de Ciencias Naturales, Bogotá (Orlando Rangel), Colombia, for the laboratory support. The Centre for Isotope Research (Groningen; Hans Van der Plicht), Netherlands Institute for Sea Research (Texel; Fred Jansen), Vrije Universiteit Amsterdam (Jef Vandenberghe), TNO (Utrecht, Wim Westerhof; deceased), and Mirella Groot and Giovanni Bogotá-A are greatly acknowledged, for their contributions to various research projects. We thank Catalina Giraldo-Pastrana for the visualization, which has been supported financially by the Hugo de Vries Fonds (Amsterdam).

Financial support. This research has been supported by the Netherlands Foundation for the Advancement of Tropical Research (WOTRO, grant nos. W75-168, WB84-552 and WB84-636), the Netherlands Organization for Scientific Research (NWO, grant nos. H75-284/CCH, 854.00.007/ALW, 2012/13248/ALW), the University of Amsterdam grants, Hugo de Vries Foundation (Amsterdam), AlBAN/EU (grant no. E04D033907CO), and the European Research Council (ERC) under the European Union's Horizon 2020 research and innovation program (grant no. 741413).

Review statement. This paper was edited by Ulrich Harms and reviewed by C. Jaramillo and one anonymous referee.

\section{References}

Adam, D. P., Sims, J. D., and Throckmorton, C. K.: $130000-$ yr continuous pollen record from Clear Lake, Lake County, California, Geology, 9, 373-377, https://doi.org/10.1130/00917613(1981)9<373:YCPRFC >2.0.CO;2, 1981.

Adam, D. P., Sarna-Wojcicki, A. M., Rieck, H. J., Bradbury, J. P., Dean, W. E., and Forester, R. M.: Tulelake, California: the last 3 million years, Paleogeogr. Paleoclimatol. Paleoecol., 72, 89-103, https://doi.org/10.1016/0031-0182(89)90134-X, 1989.

Andersen, K. K., Azuma, N., Barnola, J. M., Bigler, M., Biscaye, P., Caillon, N., Chappellaz, J., Clausen, H. B., Dahl-Jensen, D., Fischer, H., Flückiger, J., Fritzsche, D., Fujii, Y., Goto-Azuma, K., Grønvold, K., Gundestrup, N. S., Hansson, M., Huber, C., Hvidberg, C. S., Johnsen, S. J., Jonsell, U., Jouzel, J., Kipfstuhl, S., Landais, A., Leuenberger, M., Lorrain, R., Masson-Delmotte, V., Miller, H., Motoyama, H., Narita, H., Popp, T., Rasmussen, S. O., Raynaud, D., Rothlisberger, R., Ruth, U., Samyn, D., Schwander, J., Shoji, H., Siggard-Andersen, M. L., Steffensen, J. P., Stocker, T., Sveinbjörnsdóttir, A. E., Svensson, A., Takata, M., Tison, J. L., Thorsteinsson, T., Watanabe, O., Wilhelms, F., White, J. W., and North Greenland Ice Core Project Members: High-resolution record of Northern hemisphere climate extending in to the last interglacial period, Nature, 431, 147-151, https://doi.org/10.1038/nature02805, 2004.

Andriessen, P. A. M., Helmens, K. F., Hooghiemstra, H., Riezebos, P. A., and Van der Hammen, T.: Absolute chronology of the Pliocene-Quaternary sediment sequence of the Bogotá area, Colombia, Quaternary Sci. Rev., 12, 483-501, https://doi.org/10.1016/0277-3791(93)90066-U, 1993.

Berrío, J. C. and Hooghiemstra, H.: Information on Fúquene Pollen Data, University of Leicester, https://www2.le.ac.uk/ departments/geography/people/jcb34, last access: 2 February 2022.

Bogotá-A., R. G., Groot, M. H. M., Hooghiemstra, H., Lourens, L. J., Van der Linden, M., and Berrío, J. C.: Rapid climate change from north Andean Lake Fúquene pollen records driven by obliquity: implications for a basin-wide biostratigraphic zonation, Quaternary Sci. Rev., 30, 3321-3337, https://doi.org/10.1016/j.quascirev.2011.08.003, 2011.

Bogotá-A, R. G., Hooghiemstra, H., and Berrio, J.-C.: North Andean environmental and climatic change at orbital to submillennial time-scales: vegetation, waterlevels and sedimentary regimes from lake Fúquene from 284 to $130 \mathrm{ka}$, Rev. Palaeobot. Palynol., 226, 91-107, https://doi.org/10.1016/j.revpalbo.2015.09.007, 2015.

Boschman, L. M.: Andean mountain building since the Late Cretaceous: a paleoelevation reconstruction, Earth-Sci. Rev., 220, 103640, https://doi.org/10.1016/j.earscirev.2021.103640, 2021.

Chacón-Moreno, E., Rodriguez-Morales, M., Paredes, D., Suárez del Moral, P., and Albarrán, A.: Impacts of global change on the spatial dynamics of treeline in Venezuelan Andes, Front. Ecol. Evol., 9, 615223, https://doi.org/10.3389/fevo.2021.615223, 2021.

Dansgaard, W., Johnson, S. J., Møller, J., and Langway Jr., C. C.: One thousand centuries of climate record from Camp Century on the Greenland ice sheet, Science, 166, 377-380, https://doi.org/10.1126/science.166.3903.377, 1969. 
Dansgaard, W., Clausen, H. B., Gundestrup, N., Hammer, C. U., Johnsen, S. F., Kristinsdottir, P. M., and Reeh, N.: A new Greenland deep ice core, Science, 218, 1273-1277, https://doi.org/10.1126/science.218.4579.1273, 1982.

De Beaulieu, J. L. and Reille, M.: A long Upper Pleistocene pollen record from Les Echets, near Lyon, France, Boreas, 13, 111-132, https://doi.org/10.1111/j.1502-3885.1984.tb00066.x, 1984.

Emiliani, C.: Temperature and age analysis of deep-sea cores, Science, 1235, 383-385, https://doi.org/10.1126/science.125.3244.383, 1957.

Emiliani, C.: Isotopic paleotemperatures, Science, 154, 851-857, https://doi.org/10.1126/science.154.3751.851, 1966.

Emiliani, C.: Pleistocene paleotemperatures, Science, 168, 822825, https://doi.org/10.1126/science.168.3933.822, 1970.

Flantua, S. G. A.: Inventory of modern and paleo-records of pollen in Latin America, Latin America Pollen Database, https://www. latinamericapollendb.com/, last access: 2 February 2022.

Flantua, S. G. A. and Hooghiemstra, H.: Historical connectivity and mountain biodiversity, in: Mountains, climate and biodiversity, edited by: Hoorn, C., Perrigo, A., and Antonelli, A., Wiley, UK, 171-185, ISBN 9781119159896, 2018.

Flantua, S. G. A., Hooghiemstra, H., Van Boxel, J. H., Cabrera, M., González-Carranza, Z., and González-Arango, C.: Connectivity dynamics since the Last Glacial Maximum in the northern Andes; a pollen-driven framework to assess potential migration, in: Paleobotany and Biogeography: A Festschrift for Alan Graham in His 80th Year, edited by: Stevens, W. D., Montiel, O. M., and Raven, P. H., Missouri Botanical Garden, St. Louis, 98-123, ISBN 978-0-915279-97-5, 2014.

Flantua, S. G. A., Hooghiemstra, H., Grimm, E. C., Behling, H., Bush, M. B., González-Arango, C., Gosling, W., Ledru, M.-P., Lozano-García, S., Maldonado, A., Prieto, A., Rull, V., and Van Boxel, J. H.: Updated site compilation of the Latin American Pollen Database; challenging new research, Rev. Palaeobot. Palynol., 223, 104-115, https://doi.org/10.1016/j.revpalbo.2015.09.008, 2015.

Flantua, S. G. A., O'Dea, A., Onstein, R., Giraldo, C., and Hooghiemstra, H.: The flickering connectivity system of the north Andean páramos, J. Biogeogr., 46, 1808-1825, https://doi.org/10.1111/jbi.13607, 2019.

Flenley, J. F.: Andean guide to Pliocene-Quaternary climate, Nature, 311, 702-703, https://doi.org/10.1038/311702b0, 1984.

Flenley, J. R.: A long land-based core, J. Biogeogr., 12, 192-194, https://doi.org/10.2307/2844844, 1985.

Florschütz, F., Menéndez Amor, J., and Wijmstra, T.A.: Palynology of a thick Quaternary succession in southern Spain, Palaeogeogr. Palaeoclimatol. Palaeoecol., 10, 233-264, https://doi.org/10.1016/0031-0182(71)90049-6, 1971.

France, I., Duller, A. W. G., Duller, G. A. T., and Lamb, H. F.: A new approach to automated pollen analysis, Quaternary Sci. Rev., 19, 537-546, https://doi.org/10.1016/S0277-3791(99)00021-9, 2000.

Gibbard, P. L., Head, M. J., and Walker, M. J. C.: Formal ratification of the Quaternary System/Period and the Pleistocene Series/Epoch with a base at $2.58 \mathrm{Ma}$, J. Quat. Sci., 25, 96-102, https://doi.org/10.1002/jqs.1338, 2010.

Giraldo, C., Flantua, S. G. A., and Hooghiemstra, H.: Sky Islands: A time travel of the Andes Mountains, figshare [video], https://figshare.com/articles/Appendix_6_Visualization_of_
the_flickering_connectivity_system_in_the_Northern_Andes/ 7408643, last access: 2 February 2022.

González-Carranza, Z., Hooghiemstra, H., and Vélez, M. I.: Major altitudinal shifts in Andean vegetation on the Amazonian flank show temporary loss of biota in the Holocene, Holocene, 22, 1227-1241, https://doi.org/10.1177/0959683612451183, 2012.

Groot, M. H. M., Bogotá, R. G., Lourens, L. J., Hooghiemstra, H., Vriend, M., Berrio, J. C., Tuenter, E., Van der Plicht, J., Van Geel, B., Ziegler, M., Weber, S. L., Betancourt, A., Contreras, L., Gaviria, S., Giraldo, C., González, N., Jansen, J. H. F., Konert, M., Ortega, D., Rangel, O., Sarmiento, G., Vandenberghe, J., Van der Hammen, T., Van der Linden, M., and Westerhoff, W.: Ultra-high resolution pollen record from the northern Andes reveals rapid shifts in montane climates within the last two glacial cycles, Clim. Past, 7, 299-316, https://doi.org/10.5194/cp-7-2992011, 2011.

Groot, M. H. M., Hooghiemstra, H., Berrio, J.-C., and Giraldo, C.: North Andean environmental and climatic change at orbital to submillennial time-scales: vegetation, waterlevels, and sedimentary regimes from Lake Fúquene during 130-27 ka, Rev. Palaeobot. Palynol., 197, 186-204, https://doi.org/10.1016/j.revpalbo.2013.04.005, 2013.

Groot, M. H. M., Van der Plicht, J., Hooghiemstra, H., Lourens, L. J., and Rowe, H. D.: Age modelling for Pleistocene lake sediments: a comparison of methods from the Andean Fúquene Basin (Colombia) case study, Quat. Geochron., 22, 144-154, https://doi.org/10.1016/j.quageo.2014.01.002, 2014.

Hooghiemstra, H.: Vegetational and climatic history of the high plain of Bogotá, Colombia, Doctoral dissertation, University of Amsterdam, Dissertationes Botanicae, 79, 1-368, Cramer, Vaduz, ISBN 3-7682-1404-4, 1984.

Hooghiemstra, H. and Flantua, S. G. A.: Colombia in Quaternary: an overview of environmental and climatic change, in: The Geology of Colombia Book, edited by: GómezTapias, J., Servicio Geológico Colombiano, vol. 4, 43-104, https://doi.org/10.32685/pub.esp.38.2019, 2019.

Hooghiemstra, H. and Hoek, W. Z.: Waldo Heliodoor Zagwijn (1928-2018): the instigator and architect of European chronostratigraphy, Neth. J. Geosci., 98, e7, https://doi.org/10.1017/njg.2019.9, 2019.

Hooghiemstra, H. and Van der Hammen, T.: Quaternary ice-age dynamics in the Colombian Andes: developing an understanding of our legacy, Phil. Trans. Roy. Soc. London B, 359, 173-181, https://doi.org/10.1098/rstb.2003.1420, 2004.

Hooghiemstra, H., Mélice, J. L., Berger, A., and Shackleton, N. J.: Frequency spectra and paleoclimatic variability of the high-resolution 30-1450 ka Funza I pollen record (Eastern Cordillera, Colombia), Quaternary Sci. Rev., 12, 141-156, https://doi.org/10.1016/0277-3791(93)90013-C, 1993.

Hooghiemstra, H., Wijninga, V. M., and Cleef, A. M.: The paleobotanical record of Colombia: implications for biogeography and biodiversity, Ann. Missouri Bot. Gard., 93, 297-324, https://doi.org/10.3417/00266493(2006)93[297:TPROCI]2.0.CO;2, 2006.

Hoorn, C., Wesselingh, F. P., Ter Steege, H., Bermudez, M. A., Mora, A., Sevink, J., Sanmartín, I., Sanchez-Meseguer, A., Anderson, C. L., Figueiredo, J. P., Jaramillo, C., Riff, D., Negri, F. R., Hooghiemstra, H., Lundberg, J., Stadler, T., Särkinen, T., and Antonelli, A.: Amazonia through time: Andean uplift, cli- 
mate change, landscape evolution, and biodiversity, Science, 330, 927-931, https://doi.org/10.1126/science.1194585, 2010.

Kukla, G.: Long continental records of climate; an introduction, Paleogeogr. Palaeoclimatol. Palaeoecol., 72, 1-9, https://doi.org/10.1016/0031-0182(89)90128-4, 1989.

Libby, W. F., Andersen, E. C., and Arnold, J. R.: Age determination by radiocarbon content: world wide assay of natural radiocarbon, Science, 109, 227-228, https://doi.org/10.1126/science.109.2827.227, 1949.

Lisiecki, L. E. and Raymo, M. E.: A Pliocene-Pleistocene stack of 57 globally distributed benthic $\partial^{18} \mathrm{O}$ records, Paleoceanogr., 20, PA1003, https://doi.org/10.1029/2004PA001071, 2005.

Mommersteeg, H.: Vegetation development and cyclic and abrupt climatic change during the late Quaternary, Doctoral dissertation, University of Amsterdam, 191 pp., ISBN 90-9011649-4, 1998.

PAGES: Continental drilling for paleoclimatic records. Recommendations from an international workshop, edited by: Colman, S. M., Workshop Continenal Drilling for Paleoclimatic Recods, 30 June-2 July 1995, GeoForschungsZentrum, Postdam, Germany, Series 1996-4, 104 pp., 1996.

Pons, A. and Reille, M.: The Holocene and upper Pleistocene pollen record from Padul (Granada, Spain): a new study, Palaeogeogr. Palaeoclimatol. Palaeoecol., 66, 243-249, https://doi.org/10.1016/0031-0182(88)90202-7, 1988.

Restrepo-Moreno, S. A., Foster, D. A., Bernet, M., Min, K., and Noriega, S.: Morphotectonic and orogenic development of the Northern Andes of Colombia: a low-temperature thermochronology perspective, in: Geology and tectonics of northwestern South America, edited by: Cediel, R. and Shaw, R. P., Springer, Frontiers in Earth Sciences, 749-832, https://doi.org/10.1007/978-3319-76132-9_11, 2019.

Sarmiento, G., Gaviria, S., Hooghiemstra, H., Berrio, J.-C., and Van der Hammen, T.: Landscape evolution and origin of Lake Fúquene (Colombia): tectonics, erosion and sedimentation processes during the Pleistocene, Geomorph., 100, 563-575, https://doi.org/10.1016/j.geomorph.2008.02.006, 2008.

Shackleton, N. J.: Oxygen isotopes, ice volume and sea level, Quat. Sci.Rev., 6, 183-190, https://doi.org/10.1016/00335894(84)90085-1, 1987.

Tiedeman, R., Sarnthein, M., and Shackleton, N. J.: Astronomic timescale for the Pliocene Atlantic $\partial^{18} \mathrm{O}$ and dust flux records of Ocean Drilling Program site 659, Paleoceanogr., 9, 619-638, https://doi.org/10.1029/94PA00208, 1994.

Torres, T., Valle, M., Ortiz, J. E., Soler, V., Araujo, R., Rivas, M. R., Delgado, A., Julià, R., and Sánchez-Palencia, Y.: $800 \mathrm{ka}$ of Palaeoenvironmental changes in the southwestern Mediterranean realm, J. Iberian Geol., 46, 117-144, 2020.

Torres, V., Vandenberghe, J., and Hooghiemstra, H.: An environmental reconstruction of the sediment infill of the Bogotá basin (Colombia) during the last 3 million years from abiotic and biotic proxies, Palaeogeogr. Palaeoclimatol. Palaeoecol., 226, 127148, https://doi.org/10.1016/j.palaeo.2005.05.005, 2005.

Torres, V., Hooghiemstra, H., Lourens, L. J., and Tzedakis, P. C.: Astronomical tuning of long pollen records reveals the dynamic history of montane biomes and lake levels in the tropical high Andes during the Quaternary, Quaternary Sci. Rev., 63, 59-72, https://doi.org/10.1016/j.quascirev.2012.11.004, 2013.

Torres Torres, V.: Pliocene-Pleistocene evolution of flora, vegetation and climate: a palynological and sedimentological study of a 586-m core from the Bogotá basin, Colombia, Doctoral dissertation, University of Amsterdam, 181 pp., ISBN 90-76894-64-7, 2006.

Tzedakis, P. C., De Beaulieu, J.-L., Crowhurst, S., Follieri, M., Hooghiemstra, H., Magri, D., Reille, M., Shackleton, N. J., and Wijmstra, T. A.: Comparison of terrestrial and marine records of changing climate of the last 500000 years, Earth Planet. Sc. Lett., 150, 171-176, https://doi.org/10.1016/S0012-821X(97)00078-2, 1997.

Tzedakis, P. C., Andrieu, V., De Beaulieu, J.-L., Birks, H. J. B., Crowhurst, S., Follieri, M., Hooghiemstra, H., Magri, D., Reille, M., Sadori, L., Shackleton, N. J., and Wijmstra, T. A.: Establishing a terrestrial chronological framework as a basis for biostratigraphical comparisons. Quaternary Sci. Rev., 20, 1583-1592, https://doi.org/10.1016/S0277-3791(01)00025-7, 2001.

Tzedakis, P. C., Hooghiemstra, H., and Palike, H.: The last 1.35 milion years at Tenaghi Philippon: revised chronostratigraphy and long-term vegetation trends, Quaternary Sci. Rev., 25, 34163430, https://doi.org/10.1016/j.quascirev.2006.09.002, 2006.

Van der Hammen, T.: Climate and vegetational succession in the equatorial Andes of Colombia, in: Geo-ecology of the mountainous regions of the tropical Americas, edited by: Troll, C., Coll. Geogr., 9, 187-194, 1968.

Van der Hammen, T.: The Pleistocene changes of vegetation and climate in the Northern Andes, in: The glaciation of the Ecuadorian Andes, edtied by: Hastenrath, S., Balkema, Rotterdam, 125-145, ISBN 90-6191-038-2, 1981.

Van der Hammen, T.: Plan ambiental de la cuenca alta del Río Bogotá, Corpocación Autónoma Regional (CAR) de Cundinamarca, Bogotá, 142 pp., http://sie.car.gov.co/bitstream/handle/ 20.500.11786/33796/28263.pdf?sequence=1\&isAllowed=y (last access: 4 February 2022), 1998.

Van der Hammen, T. and Hooghiemstra, H.: Interglacial-glacial Fúquene-3 pollen record from Colombia: an Eemian to Holocene climate record, Glob. Planet. Change, 36, 181-199, https://doi.org/10.1016/S0921-8181(02)00184-4, 2003.

Van der Hammen, T., Wijmstra, T. A., and Van der Molen, W. H.: Palynological study of a very thick peat section in Greece and the Würm-glacial vegetation in the Mediterranean region, Geol. Mijnb., 44, 37-39, 1965.

Van der Hammen, T., Wijmstra, T. A., and Zagwijn, W. H.: The floral record of the late Cenozoic of Europe, in: Late Cenozoic glacial ages, edited by: Turekian, K. K., Yale Univ. Press, 391424, ISBN 0-300-01420-1, 1971.

Van der Hammen, T., Werner, J. H., and Van Dommelen, H.: Palynological record of the upheaval of the Northern Andes; a study of the Pliocene and Lower Quaternary of the Colombian Eastern Cordillera and the early evolution of its highAndean biota, Palaeogeogr. Palaeoclimatol. Palaeoecol., 16, 1122, https://doi.org/10.1016/0034-6667(73)90031-6, 1973.

Van Geel, B. and Van der Hammen, T.: Upper Quaternary vegetational and climatic sequence of the Fúquene area (Eastern Cordillera, Colombia), Palaeogeogr. Palaeoclimatol. Palaeoecol., 14, 9-92, https://doi.org/10.1016/0031-0182(73)90064-3, 1973.

Vriend, M., Groot, M. H. M., Hooghiemstra, H., BogotáAngel, R. G., and Berrio, J. C.: Changing depositional environments in the Colombian Fúquene Basin at submillennial time-scales during $284-27 \mathrm{ka}$ from unmixed grain-size distri- 
butions and aquatic pollen, Neth. J. Geosci., 91, 199-214, https://doi.org/10.1017/S0016774600001591, 2012.

Wijmstra, T. A.: Palynology of the first 30 metres of a $120 \mathrm{~m}$ deep section in Northern Greece, Acta Bot. Neerl., 18, 511-527, https://doi.org/10.1111/j.1438-8677.1969.tb00591.x, 1969.

Wijninga, V. M.: Neogene ecology of the Salto de Tequendama site (2475 m alt. Cordillera Oriental, Colombia): the paleobotanical record of montane and lowland forests, Rev. Palaeobot. Palynol., 92, 97-156, 1996.

Williams, J. W., Grimm, E. C., Blois, J. L., Charles, D. F., Davis, E. B., Goring, S. J., Graham, R. W., Smith, A. J., Anderson, M., Arroyo-Cabrales, J., Ashworth, A. C., Betancourt, J. L., Bills, B. W., Booth, R. K., Buckland, P. I., Curry, B. B., Giesecke, T., Jackson, S. T., Latorre, C., Nichols, J., Purdum, T., Roth, R. E., Stryker, M., and Takahara, H.: The Neotoma Paleoecology Database, a multiproxy, international, community-curated data resource, Quaternary Res., 89, 156177, https://doi.org/10.1017/qua.2017.105, 2018.
Woillard, G. M.: Grande Pile peat bog: a continuous pollen record for the last 140000 years, Quaternary Res., 12, 152-155, https://doi.org/10.1016/0033-5894(78)90079-0, 1978.

Zagwijn, W. H.: Aspects of the Pliocene and early Pleistocene vegetation of the Netherlands, Meded. Geol. Stichting, Serie C-III1(5), 1-78, 1960.

Zagwijn, W. H.: The beginning of the ice age in Europe and its major subdivisions, Quaternary Sci. Rev., 11, 583-591, https://doi.org/10.1016/0277-3791(92)90015-Z, 1992. 